\title{
3 Lost land of bliss
}

\section{Imagined temporalities of the Nordic welfare state}

\author{
Ainur Elmgren
}

In the early modern imagination, the golden age of ancient mankind proceeded inevitably towards decadence. At the dawn of the Industrial Revolution, a new way of conceptualizing temporality took form. Progress would lead humanity and the nation towards future perfection. ${ }^{1}$ In the second half of the 20th century, the Scandinavian or Nordic welfare states integrated aspects of this faith in progress into their identities. In practice, Sweden came to symbolize this aspiration, both internally and outwardly. Historian Bo Stråth has written about a peculiar "Swedish feeling of chosenness" in his study on the labour unions and the Swedish model. ${ }^{2}$ Finnish nationalism viewed Finland as "chosen", too - but the Finnish rhetoric of "chosenness" has been dominated by the experiences of war, suffering, and loss. Historian Jussi Kurunmäki notes that, while Finland has been discussed "as a survivor" in the literature of democratization and interwar crisis, Sweden has appeared as an example of "successful social democratic reformism". ${ }^{3}$

Towards the end of the 20th century, the welfare state project's very existence was questioned. The "end of history" and the victory of liberal democracy were announced during the reception of Francis Fukuyama's famous book partly simplifying its message. Two of the bastions of Nordic neutrality fell as Finland and Sweden joined the European Union. Today, the political arenas of Sweden and Finland accommodate parties that arguably promote welfare state nationalism. These parties were funded in the 1990s, but they lay claim to the "true" heritage of their respective nation-states. Has nostalgia replaced visions of future glory regarding the Nordic welfare state? It can be argued that protest parties are attempting to take control of the national narrative. The continuity of history is established retroactively. All political actors participate in this "retconning" process. This chapter explores such imagined, constructed temporalities of the Nordic welfare state from the perspective of the original liberal critics of the welfare state project and through their uses of toponyms associated with utopia.

Mythical and literary place names used for the land of bliss, such as lintukoto in Finland and the more generic lyckoland (land of bliss) in Sweden, are here used as a red thread leading the narrative from the beginnings of the welfare state project to its nostalgic denouement during the last three decades. Such 
concepts have an even longer heritage in the former realm of Sweden, which Finland was split off from in 1809. As historian Joachim Östlund states in his study on the legitimization of power in Swedish public rhetoric in the early modern and modern eras, the idyllic portrayal of the country as a "land of bliss" has shown "remarkable continuity" over the centuries, but it was not until the late 19th century that the people as a nation began to be imagined as a unit independent from God or Crown. The utopian "land of bliss" could become immanent as a union of convenience: "the rhetoric from above somewhere has to meet the dreams from below - in a Land of Bliss". 4

In Finnish public discourse, the folkloristic-literary expression lintukoto (lit. bird's abode; figuratively, safe haven) is often used to denote an imagined utopia of peace and harmony. In early modern folk belief, it was an island at the rim of the Earth disc where the sky was low and the people consequently small in stature. The migratory birds would spend the winters there. Paradoxically, the name of this exotic imaginary place is today often used for Finland, specifically a lost idyllic past.

Lintukoto was first mentioned in print in the dictionary of Erik Schroderus of Uppsala in $1637 . .^{5}$ Folk beliefs about little people that live at the edge of the earth's disc, as well as lands far away where the migratory birds spend the winter, have been recorded around the world. In an ancient Greek version of the myth, mentioned in the Iliad, "pygmies" live on the shore of the worldencircling river Oceanus, where they wage war against the cranes. ${ }^{6}$ While the pygmies of ancient Greek myths tended to live in the south or southeast, early modern authors placed them sometimes in the far north - most famously Swedish cosmographer Olaus Magnus in his Historia de gentibus septentrionalibus (1555). ${ }^{7}$ Finnish folklore was conflated with classical references in the works of 18th-century folklorist Christfrid Ganander and 19th-century poet Aleksis Kivi. ${ }^{8}$ Lintukoto and its tiny inhabitants achieved literary status through an eponymous poem by Kivi, published in 1866. Kivi infused the folkloric tale with the isle of bliss topos, inherited from German and Scandinavian Romanticism. Unlike the mythical pygmies, Kivi's little people (kerikansa) did not fight migratory birds but happily rode on swans around their "isle of peace". 9

Kivi's idyll influenced successive generations of Finnish writers. Folklorists used Kivi's poem as a testimony of the enduring power of native beliefs in the spirit of late national romanticism. Literary scholar Toni Lahtinen states that Kivi's poem has been seen as historically significant as a reworking of a universal topos "into a Finnish, that is, national, land of bliss". ${ }^{10}$ It foreshadowed the imagined ideal welfare state in other ways, as Kivi - in contrast to many other literary depictions of the land of bliss as a land of leisure - showed the inhabitants happily at work, the men ploughing and mowing, the women weaving and cooking. However, Lintukoto's pronounced isolation and the small size of its inhabitants also invited pejorative uses. The poet Eino Leino, who often utilized folkloric themes in his works, compared the Finns to Kivi's kerikansa in a poem expressing disdain for narrowmindedness. His Finland was not a 
summery isle of bliss, but another land at the edge of the world, the desolate Ultima Thule. ${ }^{11}$

The Swedish concept lyckoland (or lyckorike, kingdom of bliss) overlaps the meaning of lintukoto, as redefined by Kivi. The land of bliss had been pictured as an island since antiquity. The poem Lycksalighetens $\ddot{o}$ (Isle of Bliss, 1833) by the Swedish Late Romantic Erik Johan Stagnelius, Kivi's "favourite poet", was an important source of inspiration for Lintukoto. ${ }^{12}$ Stagnelius' island is a timeless paradise where autumn's bountiful harvest can be enjoyed in "eternal May sun”, similarly to Kivi's Lintukoto. But unlike Kivi’s chaste idyll, Stagnelius' fantasy is straightforwardly erotic. ${ }^{13}$

The literary origins of Stagnelius' isle of bliss can be traced to a popular 18thcentury novel with the same name, a translation of a 1690 novelization of a traditional French fairy tale by Marie-Catherine d'Aulnoy. The tale inspired an eponymous play by Per Daniel Amadeus Atterbom from 1824. In this version, King Astolf leaves his native Hyperborea - another mythological allusion - for the isle of bliss, where he enjoys opulence and immortality with the appropriately named Felicia. After 300 years, Astolf returns to his northern homeland and finds it transformed: monarchy and nobility have been abolished, and the former subjects have lost their warlike honour. Instead, they waste their time on speeches and newspapers and get burdened with ever-increasing taxes. ${ }^{14}$ Atterbom's Hyperborea foreshadows the 20th-century welfare state dystopia, although his targets were the liberals of his time. ${ }^{15}$ Neither Stagnelius' poem, nor Atterbom's play, were ever translated to Finnish, but this was no obstacle for the largely Swedish-speaking Finnish intelligentsia of the 19th century. ${ }^{16}$

From these 19th-century exchanges of cultural tropes grew a literary tradition that contrasted the dream of perfect happiness with the nightmare of failure and loss. Throughout the 20th century, lyckoland was used in the sense of utopia or fairy-tale land of happiness in the Swedish language. The uses of the trope revealed awareness of its impossibility - Stagnelius' erotic idyll could only be reached through the imagination, and Atterbom's island of eternal beauty was a golden cage. These connotations made lyckoland an apt trope of political satire, for example in August Strindberg's Robinsonade De lycksaliges $\ddot{o}$ ("The Isle of the Blissful Ones") from 1882. ${ }^{17}$ Until the mid-1930s, lyckoland was mainly used in Dagens Nyheter as a satirical description of the Soviet Union or, in a milder tone, of the United States as a destination for immigrants. It is as a description of migrants' hopes that the concept returns in the 1980s, but between these decades, it is also increasingly used for Sweden and the progressive project of the Social Democratic Party.

In comparison to the concepts folkhem (people's home, originally a conservative metaphor appropriated by the Swedish Social Democrats) ${ }^{18}$ or välfärdsstaten (the welfare state), usually describing something realized in the present, the land of bliss is a place in the immediate future or the near past. If it is overlapping with the present, it is usually employed with an ironic meaning. The liberal critics of the welfare state began applying the terms ironically and reluctantly to contemporary society and increasingly adopted the terms as national 
self-definitions, until a turning point in 1989-1992. Around and after those dates, the terms are used in a nostalgic or moralizing sense to denote a lost era, but there have also been attempts to reclaim land of bliss as a cautiously optimistic future vision. ${ }^{19}$

\section{Visions of Nordic progress}

The connection between the Nordic countries and the land of bliss, as well as its dark side, preceded the modern welfare state. Hyperborea and Ultima Thule of ancient myth could be imagined as the two sides of the same coin - happy Hyperborea representing the nightless summer in the far north, and miserable Ultima Thule wrapped in endless winter dusk. The name Scandia, originally a Mediterranean toponym, was used for islands in Northern Europe by Greek and Roman geographers. By reinterpreting the works of Jordanes, who created a glorification of Gothic history in the 6th century, Early Modern Swedish scholar Olof Rudbeck the Elder resurrected the idea of Scandza/Scandinavia as an island - literally or metaphorically - for political purposes. ${ }^{20}$ Rudbeck's Sweden, the state that was destined to rule Scandinavia, was not just any island, or peninsula - it was the mythical Atlantis that would rise again and relive its glorious past. ${ }^{21}$ According to Rudbeck, already the ancient Greeks had "not without reason" testified that Sweden was "the isle of the Gods, the Kings, the High-Born, and the Blissful” (de Lycksaligas ö). ${ }^{22}$

Rudbeck's ideas were revived in the early 19th century after the loss of Finland. Although Finnish national romanticists were influenced by this "NeoGothicist" movement, they kept their work locally focused. With the rise of Finnish nationalism, the isle of bliss could be found in Finland itself. In a collection of children's stories in 1891, prolific author Zacharias Topelius combined the latest geological findings about post-glacial rebound in the Baltic Sea with folklore and national romantic poetry in his tale of the rise of an isle of bliss from the depths of the sea. ${ }^{23}$ In Topelius' version, the isle of bliss consists of both Scandinavia and Finland. Happiness is disrupted by a jealous Arctic sorceress. She sends giants to unite the island with Asia by a land bridge. The isle of bliss transforms into a mundane peninsula "where paths of nations cross, where powers struggle, where hounds hunt, worries wake and sorrows cast their shadows upon glimpses of sunshine. Where, where is the isle of bliss?" 24 Topelius assures the reader that it lives on in the pure hearts of Finnish children. ${ }^{25}$ The progress of post-glacial rebound became a metaphor for societal progress as a moral duty. The rising land was a gift from God, a miracle that distinguished Finland among the nations. Hence, the children of Finland have inherited the Christian duty to serve as stewards over God's creation and "grow, like the land, in body and soul, wisdom and mercy ... to leave [the land] better off than you once received it". ${ }^{26}$

In the Nordic countries, the idea of progress became central to several political movements, including patriotic movements of civil rights and national liberation, the labour movement, the temperance movement, and liberal parties 
and associations. Christians like Topelius could embrace ideas of societal progress as a service to God. For a long time, the progressive land of bliss was not identified as actually present. Such utopian visions were, on the contrary, often mocked and parodied. All "lands of bliss" were not progressive, but all were somewhat dubious; most of them were clearly fictional, such as the 1924 Ernst Rolf revue Lyckolandet, one of the most successful shows of the 20th century in Sweden. ${ }^{27}$ Much like Atterbom's isle of bliss, the revue featured orientalist exotism in costumes and scenery.

Transposed on mundane Sweden, the idyll invariably looked ridiculous. In the winning verses of a leap year poetry competition of Dagens Nyheter's humour section "Namn och Nytt", everyday nuptial harmony is promised to the presumptive groom in the style of 1936: "We shall dwell in the lands of bliss,/and our fashion shall be à la Myrdal." 28 The vision of modern marital happiness is tempered with mild irony and the mention of the fashionable social scientist couple, whose public example was extended into the private sphere.

Until the 1930s, most lyckoländer in Dagens Nyheter were either the destination of emigrants, such as the United States or Latin America, or the land of the Bolshevik revolution, the USSR. Even though the liberal newspaper could have been expected to show greater sympathy towards the "land of bliss in the West" (lyckolandet $i$ väst), it was relatively cautious. The heyday of Swedish mass emigration was over by the time of the First World War, but the fear of depopulation and the moral doubts left their effect on public discourse. ${ }^{29}$

In independent Finland, the lands of bliss lay elsewhere long into the postwar era. The independence process was a painful disillusionment culminating in a Socialist uprising and a disastrous civil war in 1918. The liberal press, along with the conservatives on the side of the victors, adopted a cautionary line towards utopianism, especially its universalist and cosmopolitan expressions. Literary critics also approached idylls with nationalist caution. In 1922, Aleksis Kivi's poem Lintukoto was praised by critic Johannes Vihtori Lehtonen for having put the stamp of Finnishness on the universal topic the isle of bliss, creating an "unbroken Finnish [emphasis in the original] poem about this eternal dream of humanity, ... that nations and social classes have tried to reach by wading through streams of blood". ${ }^{30}$ Kivi's idyll was rooted in Finnish nature and tamed with "honest Finnish farmer's work". ${ }^{31}$ Lintukoto's nature and culture was recognizably local, unlike Atterbom's exotic fantasy land. ${ }^{32}$ This localization of utopia meant that the danger of universalism - the upsetting of the existing order - was evaded. Lehtonen backed his national and moral interpretation of Lintukoto with the words of philosophers who proved the impossibility of manmade utopias: "they would not last long, humanity being what it is, for suffering and toil is its inevitable lot". ${ }^{33}$ For Lehtonen, it was important to promote Kivi's modest, national idyll "especially in current times, when man seems to need more than ever everything that is bright, fair and liberating". ${ }^{34}$ Lehtonen even reread Kivi's lullaby Sydämeni laulu (The Song of My Heart), where the child is lulled to sleep in the Hades of Finnish folklore, as an idyll of "happy 
melancholy . . . the intuitive dreaming of the happy dwellers of Lintukoto, " "painless yearning", that soon fades away". 35

Lintukoto was rarely used to describe really existing Finland until the 1960s, but it did appear sporadically in descriptions of achievements of the budding welfare state - such as small homes for young families, exhibited at the Social Museum in Helsinki in the war year $1942 .{ }^{36}$ The connection between lintukoto and the smallness of its inhabitants was not lost, as well as the idea that lintukoto was only a temporary haven from the evil of the real world. ${ }^{37}$ The name had an appeal for holidaymakers and was used as a name for summer cottages (along with Onnela, literally a place of bliss). ${ }^{38}$ This might have been due to the influence of author Joel Lehtonen, who used Lintukoto as the name of his countryside retreat in the prose work Lintukoto (1929) and the posthumous poetry collection Hyvästijättö Lintukodolle ("Farewell to Lintukoto”) from $1934 .{ }^{39}$

Joel Lehtonen's private Lintukoto was an island in the lake Vanajavesi in southern Finland. Even though Lehtonen pictured the island as an escape, a "sovereign realm" or a monastery "in splendid isolation", his island was not an abode of indolent bliss. Every living creature on the island participated in the struggle for survival. The blue flower of Romanticism was the humble cornflower in the rye field, a product of the previous settler's hard work. ${ }^{40}$ Lehtonen distanced his island dreams from the pretentious and hedonistic "rascals" of the European Robinsonade and picaresque literature. ${ }^{41}$ Finally, he abandoned his island shortly before his own death. Literature scholar Juhani Niemi sees in Lehtonen's two Lintukoto works a pastoral idyll with traits of parody and even apocalyptic elements. The topos Lintukoto turns into an atopos, a bridge to the afterlife, or to oblivion. ${ }^{42}$ Did Kivi's extinction of the idyll's Eros inevitably lead to Lehtonen's embrace of its Thanatos?

The adoption of Lintukoto as a Finnish self-description by journalists and authors coincides with the self-identification as a Nordic welfare state. In Sweden, this process was initiated a few decades earlier. On the pages of the reluctant Dagens Nyheter, it started as a satirical self-identification in the 1930s, referencing the progressive projects of folkhemmet, the Myrdals and the trend of "New Objectivity" (nya sakligheten, from the Weimar era art style Neue Sachlichkeit). ${ }^{43}$ Conservatives also employed such ironic terminology. The diplomat and writer Rütger Essén, a Nazi sympathizer, entitled one of his popular radio plays on political themes in the late 1930s "Idyllen Sverige" (Sweden the Idyll). ${ }^{44}$ Essén let a particular character, a Swedish expatriate, express his discomfort with his old homeland: the Swedes, taking the credit for peace and prosperity that was merely due to luck, "with sensible and self-wise virtuousness observe their own splendidness and distribute warning and advice to a world gone astray". ${ }^{45}$ Essén, like other radical conservatives, lamented that democracy hindered individual talents from leading. In Dagens Nyheter, Ivar Harrie reminded Essén about his relative privilege: "In authoritarian states, the police take care of [dissidents]. Democratic societies can afford to keep them around, and profit from them. Dr Essén owes the Swedish idyll much gratitude." ${ }^{46}$ 
In the face of such self-sufficiency, even from the liberal critics of the welfare state, it is not surprising that discomfort with the welfare state project had to be expressed through poetry and fiction. Finnish poet Elmer Diktonius's prose work Onnela (1925), "land of bliss", on which the poem's speaker states ambiguously: "Here I am at home - here I am in a foreign land", was still the "meagre earth" of the pre-welfare state. ${ }^{47}$ Gunnar Ekelöf's Non Serviam (1945), on the other hand, is a frustrated individualist manifesto against folkhemmet Sweden: "I am not at home in this land/but this land acts as if it is at home in me!" 48

But as foreign commentators began to praise Nordic progress, the temptation to repeat their words arose - first with mild irony, then increasingly matter-of-factly. British professor C. E. M. Joad, who visited Sweden in 1946 and identified it as the happiest country in the world, had his words repeated verbatim in Dagens Nyheter. ${ }^{49}$ However, his explanation for Sweden's happiness was not in superior social planning and "socialism without tears", but in the smallness of the population and the national temperament, or rather lack of it. The image of Nordic progressivism was created in concert with the foreign - mainly Anglo-American - discourse on Nordic particularism. Still, in 1975, when Prime Minister Olof Palme's first government made the country "unbearable politically" for many US businessmen, the magazine Business Week presented Sweden as a "land of bliss" (according to Dagens Nyheter) for business investment and a model for US lawmakers. ${ }^{50}$

Parallel to the creeping acceptance of the lyckoland identity and the breakthrough of the "golden age" of capitalism, the 1950s has been seen as the peak of the folkhemmet discourse, while self-identification as a welfare state has been seen as a feature of the 1960s. ${ }^{51}$ The notion of the Swedish idyll was losing its satirical connotations, while the original bearers of this myth were facing challenges to it. The liberal and conservative press gladly quoted the chair of the central organization of the labour unions (LO), Axel Strand, beset by the challenges of post-war inflation and the government's demands to lower expectations: "the land of bliss without difficulties and worries only exists in our dreams". ${ }^{52}$ Parallel to the land of bliss, the dystopias - "the future as a nightmare" according to writer Olof Lagercrantz in Dagens Nyheter were always present. As Lagercrantz observed, the warnings of Yevgeny Zamyatin, Aldous Huxley, and George Orwell, as well as those of the Swedes Pär Lagerkvist and Karin Boye, were inspired by the real sociopolitical projects of Nazi Germany and the Soviet Union. These authors contributed to a "horror for the future" that Lagercratz predicted would turn many countries in the West towards conservatism. The Soviet Union had killed the old utopia. $^{53}$

Lagercrantz identified very different interpretations of happiness among the dystopian writers. In Orwell, he sees no promise of even artificial happiness. The future is "a boot stamping on a human face forever", an image inherited from Jack London's Iron Heel (1908). But Zamyatin's totalitarian collective We (1920-1921) lures its inhabitants into simple happiness. Adam 
and Eve could choose between happiness without freedom and freedom without happiness - they chose freedom and became unhappy. Since then, humanity has longed for fetters. In Zamyatin's dystopia, humanity has been restored to simplicity, innocence, and chains. Similarly, Huxley shows a society where misery has been organized away, at the expense of freedom. Lagercrantz quotes the example of an elevator operator, who has been injected with a drug that makes him feel that the height of bliss is to reach the top floor. He loves his job!

Lagercrantz does not compare the worlds of Zamyatin and Huxley outright to the folkhem project, but he asks:

In the new society that we are approaching . . . we buy a little fortune cookie [lyckokaka] for freedom and unlimited personal opportunities. We swap our soul for biological satisfaction. Is such a development . . the necessary result of the new technology, the centralized state, the new mass communications and the Zamyatinesque bliss-philosophy?

There are echoes of the heritage of Protestant pietism in Lagercrantz's judgement of his contemporaries. The fulfilment of worldly desires meant "the risk of enslavement under happiness". ${ }^{44}$ Instead, one should seek the grace of God through the cultivation of virtue, above all contentment with one's lot, and use these "tools of reason" to vanquish worldly desires.

Sixteen years later, psychiatrist and writer Jan Gudmundsson echoed Lagercrantz's concerns for the psychological consequences of "biological satisfaction" in his novel Löfteslandet (The Land of Promise, 1976). The main character, Henning, was a worker suffering from a crippling anxiety evidenced by both physical and behavioural symptoms. Despite being both married and unionized, Henning felt like an outsider. According to a review in Dagens Nyheter, the utopian "myth of a worker-led welfare society" obscured reality, namely Hemming's alienation. Henning had grown up in an individualistic culture that values wealth and celebrity, in the "blinding light of the Swedish land of bliss ... the Swedish compromise". The reviewer felt that Gudmundsson gave tangible form to an almost hopeless contradiction in contemporary ideals, and the individual's consequential alienation. In "the solidarity-based 'worker-led' welfare society" all conceivable services were readily available to fulfil Hemming's needs, but availability was not the issue: "The issue is that society, in its chief and decisive normal functions, lacks solidarity." 55

Even as the contemporary age began to be identified as an age of increased welfare and happiness, the concept of happiness was tainted with the negative connotations of worldly desires. Just as in Atterbom's play, the isle of bliss cannot give the hero the freedom that he craves, and he abandons it for an ultimately fatal quest into a world that has moved on. The virtues of yore, "truth and beauty", seemed to have been dismissed as unmodern just as they were in Huxley's Brave New World. This criticism would continue to haunt the Nordic welfare state until its mysterious dislocation into the past. 


\section{The perils of progress}

The liberal critique of the socialist project - usurping the modern project at least in Sweden - from the very beginning focused on its character as a utopia (lyckorike, lyckoland), an impossible dream world of happiness. But as more and more of the promises began to come true, often with practical support of the liberals themselves, the critique changed character. ${ }^{56}$ The folkhem project began to be criticized as fulfilling every wish and therefore limiting ambition. By making everything possible, it paradoxically limited people's will to explore them. It was dangerously similar to totalitarian systems that also promised heaven on earth.

The sociologist Antti Eskola was an early Finnish critic of the conflict-less land of bliss and an early adopter of the term lintukoto for Finland. The selfdescribed "anarchist" and "ultra-democrat" Eskola was the son of a crofter from the same estate that novelist Väinö Linna immortalized in his 1959-1962 trilogy Under the North Star. In the 1950s, Eskola became a student of sociologist Erik Allardt and later eulogized this "golden age of bourgeois sociology" that aimed to utilize research in order to make democracy more accessible, increase tolerance, remove ingrained misconceptions, and help individuals and groups adapt to the structural changes in society. ${ }^{57}$

However, in 1968, Eskola painted a satirical image of this brave new society in his polemical book Suomi sulo Pohjola ("Finland Sweet North", 1968):

In this ideal Finland . . . the sun is shining, the tractors buzz in the fields and the merry roar of GDP growth is heard everywhere. The tiny lads and lasses [a reference to the pygmies inhabiting lintukoto] walk around beaming with tolerance, enduring difference and regulating conflicts. Nobody asks the fundamental questions, nobody inquires about the legitimacy of the basic rules. // There are no abnormals or antisocials. Everyone has their functional place: the communists have been integrated by receiving responsibilities. ${ }^{58}$

Eskola's lintukoto-Finland was closely inspired by Kivi's 1866 poem and even picked up some of the darker shades that Kivi had included in his description of the fairy-tale island's happy inhabitants:

In such a utopia, people are not conscious of the foundations of the social order and their own actions. Only occasionally does the hazy shadow of such a thought cross their mind, just like the inhabitants of Kivi's Lintukoto, who sometimes sink into a semblance of gloomy contemplation. In reality, they do not contemplate anything, because they cannot articulate their feeling in a question: "They seek no answer, they find none." ${ }^{9}$

Kivi scholars had puzzled over this mysterious shadow of gloom in Kivi's idyll throughout the 20th century. In the interwar era, Johannes Vihtori Lehtonen 
proposed that it reflected the premonition of death in Atterbom's play, while poet and writer Veikko Antero Koskenniemi interpreted it as an effect of prelapsarian innocence. ${ }^{60}$ Koskenniemi's interpretation foreshadowed Eskola's, who had found one flaw in the idyll: "To reduce suffering, knowledge has to be reduced." The way out of the land of ignorance-is-bliss was to bite the fruit of knowledge and create a "conscious society", to "make people painfully aware that society is founded on coercion, that we are only free to do what is currently tolerated to be done, and that we have no personality, will, or behaviour of our own independent of society". In outright religious terms, Eskola demanded that everyone become aware of their participation in a system of oppression where they were both exploited and privileged in relation to others: "Man has to comprehend that his every act is a sin; bad conscience must trouble him day and night; and mercy must be almost out of reach." ${ }_{11}$ A decent human being, a "child of Marx and Christ", had to be able to defend herself against manipulation and persuasion of the type that Stanley Milgram demonstrated in his famous study in social psychology. In Eskola's words, Milgram had revealed that "our culture did not seem to offer the individual suitable ways of refusing to obey unjust orders". ${ }^{62}$ The democratic welfare state seemed to be even more difficult to rebel against than a totalitarian state.

Helsingin Sanomat critic Teuvo Mällinen saw a contradiction in Eskola's fear of a utopia without conflict and his fear of a utopia that regulates conflict. ${ }^{63}$ Mällinen pointed out that Eskola himself had modelled democracy according to the ideals of regulation of conflict. Eskola returned to the lintukoto topic in an interview almost 30 years later. The old radical re-evaluated his views on post-war Finland, and longed for more harmonious times. "[W] no longer live safely in a lintukoto between Sweden and the Soviet Union”, he lamented. ${ }^{64}$

In 1970s literature, the toponym became more frequently associated with contemporary society, perhaps idyllic and swiftly passing, but really existing in youth culture. ${ }^{65}$ It became synonymous with the hippie movement, popularized - and perhaps institutionalized - in Finland via cultural imports such as Hair the musical. This lintukoto of youth was full of "innocent self-sufficiency", much like the Swedish idyll, and Kivi's poem was reinterpreted in light of "ideological escape", "hippie solutions", and "rock poetry" ${ }^{66}$ Perhaps the consciousness of the toponym's literary roots and its fictitiousness has been stronger in Finland, and therefore it was not easily applied to the Finnish welfare state project, a product of pragmatic compromise. It could be recognized as such in past projects, such as the research on peasant folklore, reinterpreted as an exercise in national self-sufficiency and utopianism: "In our history, romantic wanderlust did not have to escape to Medievalism or the wonders of India and El Dorado . . ., because in East Karelia was found a living legendary Atlantis, a lintukoto of antiquity", claimed historian Matti Klinge. ${ }^{67}$

Parallel to the immanentization of lintukoto, the Swedish idyll began to lose some of its ironic connotations. Critics of the welfare state like the leader of the Swedish Moderate party Gösta Bohman were forced to accept its achievements. 
These were integrated in the Swedish Moderate party's vision of the past in the book Kurs mot framtiden from 1981, where Bohman envisioned a change of tack for Sweden. ${ }^{68}$ Bohman argued that Swedish Social Democrats had chosen the way of liberalization - "freedom and change" - in the 1930s and 1950s, but since the late 1960s, socialism and stagnation had been their choice. Bohman connected his critique to conservative values of tradition by describing how "our ancestors" had preferred individual liberation before collectivism. Still, post-war Sweden had been an economic success story, and it was this positive continuity that the Moderate party set out to preserve, not disrupt. ${ }^{69}$ The progressive welfare state had reached a level of hegemony that forced even its opponents to work within its historical framework. In the 1930s, Swedish conservatives accepted democracy "because it was historical". ${ }^{70}$ Similarly, Bohman's liberal-conservatives accepted, at least temporarily, the reformist welfare state.

Gösta Bohman openly admired Social Democratic leaders like Per Albin Hansson, who had led a coalition government through the war years, and Tage Erlander, the longest-sitting prime minister in the post-war era. Bohman's vision of the happy past was, paradoxically, a national "we" of individuals working together consensually for the common good. In 1981, he criticized the "new" direction of the Social Democrats that was, in contrast to the previously conciliatory path of progress, the road to socialism, collectivism, and conflict. Thirty years later, Bohman's successor Fredrik Reinfeldt described Olof Palme as "radicalizing" the Social Democratic Party, while Erlander was part of a "Swedish tradition of consensus and spirit of concord". ${ }^{71}$

Similar signs of critique appeared in the liberal press in Finland in the early 1980s. Although the Social Democratic Party had never reached a comparable hegemonic position, some of its politicians became targets for liberal critique. For Eero Silvasti in Helsingin Sanomat, the social politician and researcher Pekka Kuusi was the architect of the "lintukoto of welfare". ${ }^{72}$ Acting mainly in the role of an expert and a civil servant, Kuusi had promoted redistribution of wealth and income as an equalizing measure. Although Silvasti admitted that neverbefore-seen levels of prosperity had been reached thanks to societal reforms in Finland, he also noted that people were experiencing dissatisfaction and unhappiness - the same paradoxical malaise of the welfare state that Swedish authors had identified in the 1960s and the 1970s. Silvasti found that "the slavery of work" had been replaced by "the slavery of consumption": "The well-meaning Pekka Kuusi ended up drawing a cage". Against the optimism of literary scholar Matti Mäkelä, who saw a glimmer of hope in the increased consumption of trainers and bicycles enabling the consumer to move and possibly even think independently from the "global gutenbergian-electromagnetic magical circle of mental stuffing", Silvasti predicted the future menace of "beltstereos" and "wristwatch-televisions". The interconnected society of the 2010 s has made his prediction come true in surprising ways, as methods of consumer manipulation, surveillance, and data processing have become increasingly refined and totalistic. 


\section{The turning point: looking back at the lost golden age}

The older idea of a golden age in the past and its descent into decadence remained alive, albeit advocated by a vocal minority. The welfare state was contested and depicted as a potential dystopia during its construction in the mid-20th century. When did the progressive "brave new world" of the future become the lost golden age of the past?

Foreign commentators influenced this turn, too. Eleven years after Olof Lagercrantz alluded to the welfare state as a Brave New World in his article series on utopia and dystopia, the British journalist Roland Huntford published the book The New Totalitarians in $1971 .{ }^{73}$ Eleven years later, Hans Magnus Enzensberger's famously anti-utopian critique of the welfare state and the Swedish model, Schwedischer Herbst, was written as an article series for Dagens Nyheter in 1982. The series was part of a greater debate under the by-line "Is Sweden Totalitarian?” echoing Huntford's book. Franz Zimmer sees Enzensberger evaluate Sweden as a heterotopia in Foucault's sense, an actually realized utopia. Enzensberger inquires about the price that the individual has had to pay to belong to this egalitarian paradise - the loss of a healthy mistrust of authority. ${ }^{74}$ According to Enzensberger, the Swedes remained in a "state of historical innocence". Did the utopia take them out of time, out of the temporal development that all other post-war nations in Western Europe were partaking of, and condemn them to eternal timeless immaturity and a nationwide regression into childhood? Enzensberger's critique was well received in Sweden. It provided an opportunity for defenders of the welfare state to respond to his abstract critique with paeans to the welfare state's actual achievements. Enzensberger's ability to express such severe criticisms was taken as proof of the fact that Sweden was not only safe and prosperous but also an open society. ${ }^{75}$

After Enzensberger, various events were used as emblems for a return to history, a loss of historical innocence: the murder of Olof Palme on 28 February 1986, the Estonia disaster in 1994, or the murder of Anna Lindh on 11 September 2003. However, such imagined turning points had already been publicized before 1986. The destruction of the land of bliss seems to be a recurring event. As early as in 1973, as historians Marie Cronqvist, Sara Kärrholm, and Lina Sturfelt have observed, a creeping suspicion had entered the Swedish public debate that something was rotten in the land of bliss. ${ }^{76}$ The year was marked by two dramatic mediatized spectacles: the hostage drama at Norrmalmstorg that would give a name to "Stockholm Syndrome" and the sudden illness and death of King Gustav VI Adolf. In May, the existence of a secret intelligence organization whose purpose was to register internal dissidents had been revealed to the public and endangered the untoppled, 40-year incumbent Social Democratic Party's victory in the coming election. Social Democrats took the opportunity to include the passing king in the rhetoric of a modern welfare state both as a "co-worker" (Erlander) and a symbol of the nation that had accepted change and become integrated harmoniously with the progressive ideals of the welfare state (Palme). ${ }^{77}$ In their responses to the king's stoic 
death-bed struggle, many members of the public expressed fears that a unique era was over, and doubted that the crown prince, more famous as a playboy than a serious worker, could fill his grandfather's shoes.

Meanwhile, the hostage drama that unfolded over several weeks at the bank at Norrmalmstorg twisted the very definitions of good and evil. The socially conscious crime novels of Maj Sjöwall and Per Wahlöö had already handled themes that now became reality as conveyed through the tabloid press. SjöwallWahlöö's crime novels laid the foundations of the genre that is now known internationally as Nordic Noir. ${ }^{78}$ Reality and fiction intertwined in a narrative of criticism against the repressive side of the welfare state. ${ }^{79}$ In Sjöwall-Wahlöö's works, Sweden was not an exceptional utopia, but a part of the Western capitalist system, sharing its burden of exploitation and guilt. The responsibility for faults in the system fell on those in power. The happy ending of the hostage drama contributed to the re-election of the Social Democratic government, which had promised "security". A few years later, the Swedish prime minister was assassinated in a Sjöwall-Wahlöö novel, eerily foreshadowing the murder of Olof Palme in 1986 that would again shake the fundaments of the Swedish land of bliss.

Interestingly, the dramatic events of 1973 had also been foreshadowed in the Finnish press in a review of an exhibition of Swedish modern art. "The people's home is malfunctioning, but why", the headline asked. The reviewer made the careful generalization that "Swedish art seems to prefer to show the malaise of society, but does not hint at a cure" ${ }^{80}$ Among the visual expressions of "the chilliness of the welfare state against the individual", the reviewer noted the skyscrapers of central Stockholm in the miniature works of Lennart Mörk and a Finnish jail cell in the works of Dick Bengtsson. Optimistically, he concluded that "stating the truth and reflecting [reality] is also progress". It is also in the 1970s that critics note how Joel Lehtonen's aforementioned literary Lintukoto also contained the destruction of utopia. The narrator follows the life of the ants on his island and sees in the ant colony "the image of an organized human utopian state". He destroys the anthill with fire like a vengeful god. ${ }^{81}$

Historian Jussi Lahtinen has shown how a Janus-faced image of progress took form in Finnish literature in the 1960s and the 1970s, the "golden age" of realist working-class novels. ${ }^{82}$ Lahtinen has limited his study to novels written by male authors, which begs the question of the welfare state malaise as a crisis of masculinity. In the novels, Finland appears on the one hand as a welfare state where the individual's standard of living and social security has improved somewhat. On the other hand, the worker protagonists experience the increasingly globally connected economy of Finland as a system that primarily benefits grand capital and the economic elite, while small entrepreneurs, wage earners and single women remain in an inferior, even exploited position. Societal problems are seen as either problems of capitalism or - similar to the liberal critique in Sweden - products of a nanny state collapsing under excessive taxation and bureaucratization. 
The new Finland was not a utopia. In the 1980s, lintukoto first appeared - if we disregard Antti Eskola's attempt in 1968 - as a denigrating description of Finland. Helsingin Sanomat's Eero Silvasti wrote a pessimistic column on the development of Finnish society entitled "Portent of Storm?" in July 1981. In Silvasti's eyes, the greatest paradox of the present was that "the feared and threatening 1980s . . . had been taken over so securely and assuredly". He saw dreadful portents in the world economy and international politics, while Finland was prospering. Just as before the First World War, Finland was industrializing thanks to the growing trade with Russia, but a bloody storm was brewing again. Finland would not be in control of that coming storm, either. For Silvasti, "the harmony of lintukoto was the eternal dream of all constructive forces", but now Finland had been "somehow secretly and half-accidentally" surprised by it, and not everyone was satisfied: "The intellectuals are muttering ... moralism in different forms raises its head and searches irrational forces for allies." The mysterious malaise that Silvasti detected was precisely the suspiciously empty consensus bemoaned by the critics of the Swedish welfare state in the 1970s and the early 1980 s - the calm before the storm. ${ }^{83}$

Other authors were also now using the term in a negative sense. Finland was a "lintukoto of culture", but this did not mean a safe haven or a blissful island, but a state of "exceptional consensus". ${ }^{84}$ Scholars and journalists equated consensus and homogeneity with social tranquillity and income policy solidarity. Their respective emphasis on correlation versus causation varied, but most of them shared the fear of a future where this package would be lost: a future of increasing inequality and increasing distinction between social groups, leaving behind the blissful years of the 1960s and the 1970s.

Swedish anti-utopian discourse was also reflected in Helsingin Sanomat's reporting on the neighbouring country. During the 1982 elections, "the people's home" was no longer in order, a commentator wrote..$^{85}$ The Social Democratic Party had spent six years in opposition, so this malaise could not be personified by the party. Instead, Olof Palme was able to claim that the bourgeois coalition government would endanger the welfare state if they continued to govern. In 1985, after the victory of Palme's party and its economic measures that were not welcomed by the labour unions, the Finnish press could still report that Swedish scholars felt confident in the future of Swedish social democracy and the concept of the egalitarian people's home. ${ }^{86}$ The Finnish reviewer, himself a researcher at Stockholm University, still had to question the idyll: "is the people's home truly so democratic and egalitarian"? Scholars, he felt, evaded the debate about "control-Sweden, the Orwellian society, where public power penetrates the private lives of people ever deeper".

The next year was a turning point. The murder of the Swedish Prime Minister Olof Palme created a shock on both sides of the Baltic Sea. Sensitive to international reactions, Swedish media reported statements such as Richard Reeves' in the New York Times: "The Swedish idyll disappeared". ${ }^{87}$ The same year, the Chernobyl disaster, paradoxically, enforced the image of Finland as 
a safe haven for all the wrong reasons. Previously unspeakable things became articulated, for "even in the Finnish lintukoto, the world today demands that a responsible minister be found who supplies information now and not on the fifteenth day". ${ }^{88}$ External threats, like ecoterrorism ${ }^{89}$ and environmental disasters, ${ }^{90}$ not internal harmony, now seemed to determine the identity of lintukoto. Even so, a happy lintukoto, even in literature, was "disgusting and unrealistic". 91 The Swedish idyll, on the other hand, was sorely missed. In 1989, journalist Mats Nörklit penned the following hopeful verses in Dagens Nyheter upon the arrest of a suspect in the Palme murder case: "He has become a symbol for our democracy/For our dream of the Swedish idyll would end/If he wasn't the one." 92

The frustration with lintukoto in Finland reached political levels. In 1987, unexpected radicals, such as Olli Rehn, the leader of the youth organization of the Centre Party, spoke at a "surprisingly fierce" student demonstration against "consensual lintukoto-Finland". ${ }^{93}$ Even the mild-mannered presidential candidate of the left, Kalevi Kivistö, was opposed to "lintukoto thinking". ${ }^{44}$ This antipathy seems surprising, considering that lintukoto was generally associated with positive ideals. However, it was also a symbol of smallness and weakness. Lintukoto, like Lehtonen's anthill, was doomed to die, and Finns were ready to kill it with fire. In 1988, historian Osmo Jussila described "the house of democracy" in the world itself as "quite a small lintukoto" in comparison with the conquests of Leninism and other "ideologies of salvation", echoing J. V. Lehtonen's 1920s juxtaposition between the purely national land of bliss and blood-drenched universalist utopia. ${ }^{95}$ The 1980 s flood of lintukoto rhetoric also covered areas like credit cards - in 1988, 40 per cent of the population were still living without debt of any kind. ${ }^{96}$ Finland became lintukoto in theatre, ${ }^{97}$ but even in the world of fiction, a Finlandized lintukoto made certain comparisons and translations impossible: a translation of an Austrian play, with all its references to the violent past and the volatile present in Central Europe, became incongruous to the critic in the context of the "peace of the Finnish lintukoto" ${ }^{98}$ If Finland's own war-torn and conflicted history seemed irrelevant as a point of comparison, had the country finally reached the point of happy oblivion that J. V. Lehtonen had hoped for, and Antti Eskola had warned against?

In 1989, the great changes in the European political landscape were greeted with surprise and also joy in Finland. Among Social Democrats, optimist and even utopian visions could be found on the rebuilding of Europe with the power of popular movements. The Åland islands, an autonomous region of Finland with a neutralized and demilitarized status, were presented as a model for Finland as a whole. This insular vision was characterized as a lintukoto by Helsingin Sanomat. ${ }^{99}$ The model of the fiercely independent island appeared as naive in light of the changing present, which inspired re-evaluations of the past and a revival of interest in the nationalist project, although "lintukoto-Finland" threatened to dilute "the fury of Finnishness into toothless tolerance". ${ }^{100}$ Despite 
such protests, the concept's insular and protectionist connotations imbued it with positive potential in the national context. For example, although markets were integrating globally, Finnish protectionism enabled a lintukoto for the vitally important forestry industry. ${ }^{101}$ Finnish nuclear energy production still trusted the bedrock "in our lintukoto". ${ }^{102}$ Thus, a nostalgic potential could be activated through the use of this concept in the right context.

The end of Finland as a lintukoto came as abruptly as the downfall of the Soviet Union. In September 1990, cinematographer Aki Kaurismäki, the great critic and nostalgist of the Finnish post-war era, announced in an interview that "the time of the lintukoto is past, unfortunately". ${ }^{103}$ Social scientist Eero Ojanen mused on the culture pages in November 1991: "It is especially amusing that the metaphor is usually employed by those debaters who belittle the meaning of national values and traditions." Ojanen pointed out that the usage of lintukoto to describe Finland was quite distinct from Kivi's 1866 poem: "a different reality somewhere else, far away where the sky and the earth meet". According to Ojanen, Kivi's escapist "Lintukoto-romance" resembled contemporary "Euro-romance" much more than homely Finland. For Ojanen, the newfound fancy for the European Union was not wrong, but "utopias ought to remain utopias ... the attempt to realize utopias has, however, often left ugly traces". ${ }^{104}$ Pace J. V. Lehtonen, Kivi's Lintukoto now lost its national character and its usefulness as a down-home utopia.

Aleksis Kivi created a related concept in the toponym Impivaara ("Virgin Hill"). This safe haven in the wilderness figured in his novel Seven Brothers (1870), the first published novel in the Finnish language. The brothers retreat to Impivaara after failing to adapt to social conventions; they return after adventures in the forest and become esteemed members of the community. In the original novel, Impivaara is a temporary retreat for the brothers, enabling them to grow from boys to men. In contemporary discourse, the place name is used in the same sense as lintukoto - a safe but lost haven. ${ }^{105}$ In the early 20th century, Impivaara was interpreted almost an ideal Thoreauesque Walden, although the novel is rather an original and almost satirical take on the Bildungsroman. Towards the end of the 20th century, the meaning of Impivaara became increasingly negative. ${ }^{106}$ Now Finns were accusing each other of being unable to adapt to the demands of progress, such as internationalization and globalization. ${ }^{107}$

When the splendid isolation of lintukoto was breached inevitably "in this present time of rupture", a strengthening of local roots and culture was offered as a protection. ${ }^{108}$ But concrete measures were needed - the first special police forces for crowd control were introduced in 1994 as "preparation for internationalization". According to a senior inspector from the Ministry of the Interior, dangerous "extremist elements might come to Finland . . this country is no longer a lintukoto". ${ }^{109}$ In 1996, the chief of police emphasized that despite the fact that the prediction of an invasion of extremist elements had not come true, "Finland was still no lintukoto". ${ }^{110}$ The imagined loss of the idyll was utilized to bolster requests for increased public funding. 


\section{The land of bliss and the other}

The 1980s and the 1990s also meant a change in the lyckoland rhetoric in the Swedish press. Earlier in the 20th century, any destination of emigrants might have been designated a lyckoland, a land of bliss, whether it really offered happiness or not: the United States, the Soviet Union, Norway, or Venezuela. ${ }^{111}$ Although Sweden had - often reluctantly - received refugees before, it was in the 1960s that Sweden itself became a lyckoland or idyll in newspaper reports about migrants and refugees, mainly in contrast to the countries that these refugees were leaving. ${ }^{112}$ In Finland, lintukoto was employed similarly in the 1980s and early 1990s. The toponym immediately conjured up its counter-concept in the form of the threatening outside world. Whereas the lintukoto of the poets, the original isle of bliss, had everyday Finland as its implicit or explicit counterimage, lintukoto-Finland expelled its own harshness to the outside world. For example, the reviewer of Günter Wallraff's book Ganz unten, translated into Finnish in 1986, where Wallraff reported on his impersonation of a Turkish guest worker, presented different reactions of Finns to the possibility of dealing with the same problems in "the northern lintukoto": "Fright: [May we never have] a migrant problem in this country! Relief: What a wise refugee policy we have! Or smugness: It's different here, foreigners are even treated too well here!" 113

Without distinction between labour migrants or political refugees, the line between push and pull factors was blurred. The word lycksökare, seeker of bliss, has a negative tone in Swedish: it can mean opportunist as well as adventurer and fortune hunter, although the meaning is connected to the expression söka sin lycka, to look for one's fortune (in the world) ${ }^{114}$ In Swedish folk belief, lycka was a limited resource that could be lost or stolen. ${ }^{115}$ In Finland, the lintukoto rhetoric carried connotations of unwillingness to share the bliss with outsiders, although this could be subverted: "I believe that in lintukoto, the mythical land of bliss, a much friendlier atmosphere is reigning than in our closed society." 116 Helsingin Sanomat returned to the topic as refugees increasingly reached Finland in the early 1990s. Municipal politicians shirking their duties in the settlement of "more than 500 refugees" were still "living in a lintukoto", but these were obviously behind the times. ${ }^{117}$

In Dagens Nyheter and Helsingin Sanomat, the idyllic concepts could be used without an obvious hint of sarcasm in news items describing the hopes and dreams of refugees and migrants. ${ }^{118}$ Visitors from Namibia were introduced to the "Swedish idyll", meaning Swedish democracy, represented by election campaigners from parties left, centre and right, in the midst of the summer greenery of the Djurgården district in Stockholm. ${ }^{119}$ Visits of international VIPs, such as the UN Secretary General, and the crises that Swedish politicians set out to solve as self-evident mediators, also provided an effective contrast to "the Swedish idyll" in newspaper copy. ${ }^{120}$ With the increasing crises in Europe during the dissolution of the Eastern Bloc, the idyllic character of Sweden could be admitted to exist - in the eyes of the Other. 
In the context of the "welfare state malaise" rhetoric published by the same newspapers, the connotation of mockery was not entirely possible to ignore. Just as the US land of bliss proved to be a disappointment to many Swedish emigrants, the Swedish lyckoland could be a trap to unhappy migrants, for example "Finns stranded in the Swedish land of bliss". ${ }^{121}$ In the early 1990s, the most reliable land of bliss was again projected into the exotic past - in the shape of a Danish-Norwegian co-production of the South Seas fantasy musical Styrman Karlsens flammer, originally performed in 1929, "a true Nordic myth about Utopia". ${ }^{122}$

Was Utopia something one could buy and consume? In 1980, an Ikea advertisement had invited Dagens Nyheter readers to a "paradise" and "land of bliss" of sofas: "not for the rich, but for the smart". ${ }^{123}$ "The Swedish idyll" appeared in real estate advertisements in the 1980s. ${ }^{124}$ It could even be utilized to attract West German companies. ${ }^{125}$ As we have seen, the literary genre of Nordic Noir achieves much of its thrills from the clash between a peaceful society and the horrors that break the illusion. Long before Stieg Larsson's Millennium trilogy, Dagens Nyheter advertised crime series contrasting the "Swedish idyll" with "the absurd, crazy and rule-breaking reality of crime". ${ }^{126}$ However, the paradox of the genre as a marketable product is that the idyll needs to be reinstated in order to be destroyed again and again. The publicity around the events that each seemed to spell the end of the Swedish idyll followed this pattern. Two years after the Palme murder, a museum advertised its exhibits with the lurid promise: "Bring your family on an expedition back in time this summer. The Swedish idyll is full of historical horrors." ${ }^{127}$ Bliss and nightmare could coexist and even depend on each other for their continuation.

If "our" land of bliss had retreated to the fantasies of past generations, what about "their" search for bliss here and now? The gaze of the Other could be constructed as deluded or greedy. The gaze on the Other could make viewers aware of their privilege. ${ }^{128}$ The Swedish idyll could be constructed as a safe haven worthy of protection, but also a reason to feel shame and guilt: "Swedish idyll as usual. . . . Seventeen-year-old boy deported to the Soviet Union. . . . Prisoners tear-gassed in Kumla". ${ }^{129}$ In the 1980s and 1990s, the topic of Swedish guilt towards the victims of the Holocaust repeatedly appeared on the culture pages of Dagens Nyheter. ${ }^{130}$ There was even something farcical about the contrast, as shown in the comedy film Leif (1987), the story of a small town that lives peacefully on the profits of its arms factory. ${ }^{131}$ The Swedish idyll had been maintained at the expense of refugees and victims of war in the same dangerous world that it tried to shield itself from.

\section{Conclusion: the cycle of Utopia and Dystopia}

With the fall of the Berlin wall, it was expected that the liberal newspapers would join the announcement of victory over disastrous utopias. In Dagens Nyheter, the young editor Johannes Åman noted in 1990 that the relatively 
recent "discovery of the future" gave radical meaning to politics. A dangerous gift, according to Leif Lewin, historian of ideas, for this discovery "led directly not to the Land of Bliss - but to Gulag and Auschwitz". If the breakdown of the Soviet bloc meant "total victory" for liberalism, future ought to lose its value as a political concept, Åman concluded. But was it really likely? Ever since the discovery of the future "as a source of inspiration for those that are dissatisfied with society", there had been no turning back, Åman wrote. Evidently, the future would continue to be used politically, for good and for evil. ${ }^{132}$

As Susan Buck-Morss notes in her monumental work on the passing of modern mass utopias, there is "real tragedy in the shattering of the dreams of modernity". Even though some goals of progress, equality, and material plenty have been reached, the grand vision remains unfulfilled, and in fact it is revealed to have been built upon immense human suffering. Indeed, she warns the reader not to confuse "the loss of the dream with the loss of the dream's realization". On "political cynicism", Buck-Morss cautions that "in denying possibilities for change it prevents them; anticipating defeat, it brings defeat into being". ${ }^{133}$ But if the promise of utopia had been annihilated and the status quo became celebrated as the end of history, what else remained to expect than dystopia?

Resentment, bitterness and lack of hope are real emotions that have been identified as driving causes behind the rise of xenophobic and welfare nationalist parties in the last three decades. ${ }^{134}$ These emotions must be taken seriously, not in the sense that scapegoating is accepted uncritically, but in the sense that the feeling of loss is not rationalized away as inevitable. The defenders of the status quo come to the defence of the achievements of the welfare state when they have become realized, or when other dystopias disguised as utopias rise to threaten the status quo, but often they rush to the barricades after the battle against economic rationality has already been lost.

To overcome pessimism about the future, how can promises of progress be formulated in the present? Today, narratives of the decay and decadence of the nation-state, the welfare state, the labour movement, and other past carriers of Progress have taken over public discourse. Concerns over retrograde "populism" inspire political actors to present their ideological projects as the only bearers of dynamic anti-change. If half of the political leaders declare that the welfare state is currently too expensive, the other half will conclude that it could be affordable in the future - if the "undeserving" were excluded.

The idea that the land of bliss was maintained at the expense of excluding others was not new. In the 1930s, in response to the violent upheavals in Europe, the "Swedish idyll" in particular was employed in contrast to the dangers of the outside world that suddenly came uncomfortably close. The cartoonist Jac (pseudonym of Carl Agnar Jacobsson, 1884-1942) ${ }^{135}$ illustrated "the Swedish idyll" in 1935 as an island populated by a family peacefully seated around their garden table, dwarfed by their big folkloristic flowers and the even bigger waves towering over their cottage. ${ }^{136}$ The similarities to Aleksis Kivi's 
poem are striking. In the very first verse, Kivi compares the fierce waves falling over the island to armies. In Jac's cartoon, only a small sign, "anchorage prohibited", stands between the isle of bliss and the raging sea.

As the progressive welfare state project became hegemonic in the 1960s and the 1970s, the arguments of its critics also began to emulate its ideals. While the environmentalist movement focused on new challenges to a global humanity, the liberal critique focused on the unfulfilled needs of the individual that collective efforts could not contain. But the malaise that its liberal critics identified in the 1970s and the early 1980s was increasingly abstract: a discomfort in modernity despite - or because of - the fact that all basic needs were provided for, which was reflected in the discomfort of Huxley's protagonist in Brave New World at the sight of his fellow human beings living out their base desires encouraged by the state.

Moral arguments and appeals to higher values such as truth and beauty were outdated, but appeals to liberty made a sudden comeback in the 1990s. By the time the welfare state started to be dismantled, welfare state nostalgia returned with a vengeance - dissatisfaction channelled by new parties, some of which had previously been anti-taxation, others of which had defended the welfare state but only for the most deserving.

In Finland, the modern project was never conclusively dominated by the Social Democratic Party. Every party and movement continued to project their own battles onto it. However, from the early 1980s until the very end of the decade, the utopia seemed to have been reached. Lintukoto - the safe and blissful haven of Finnish folklore - suddenly became immanent within the nation. Paradoxically, those who admitted that it existed seemed to be most critical of it. Lintukoto and related terms carried connotations of innocence that were no longer desirable in the 1980s but became objects of nostalgic longing in the 1990s.

\section{Notes}

1 Koselleck 2006, 159-181.

2 Stråth 1998, 12.

3 Kurunmäki 2010, 40-41.

4 Östlund 2007, 287-288.

5 Lahtinen 2017, 76.

6 Ibid., 75. Lahtinen mentions an island as the home of the pygmies, but most ancient sources do not mention it. The island theme seems to be introduced to the myth in European literature in the 16th century; see Toggweiler 2017, 1-3.

7 Toggweiler 2017, 16.

8 Lehtonen 1928, 34-35, Harva 1948, 58-60, Tanner 1954, 177-183, T. E. Uotila, "Sanat puhuvat", HS 14 December 1944.

9 Lahtinen 2017, 75-76.

10 Ibid., 76.

11 Tanner 1954, 183.

12 Lehtonen 1922, 80, Lahtinen 2017, 73.

13 Kivi removed a description of the island as a "land of love" in the second version of his poem. Lahtinen 2017, 78, Stagnelius 1833, 452. 
14 Atterbom 1827, 228-232.

15 Vetterlund 1920.

16 Lahtinen 2017, 74.

17 On Strindberg's De lycksaliges $\ddot{o}$ as political satire, see Lahtinen, Laakso \& Sagulin 2017, 19, and Niemi 2017, 104.

18 Kurunmäki 2010, 70-71.

19 Karvinen 2015.

20 Riikonen 2017, 49.

21 Lahtinen, Laakso \& Sagulin 2017, 19.

22 Eriksson 2002, 326.

23 Topelius 1891, 3-8; one influence on Topelius was Atterbom's play. Lehtonen 1928, 57.

24 Topelius 1891, 13-19.

25 Lahtinen, Laakso \& Sagulin 2017, 9.

26 Topelius 1891, 19.

27 Lagerroth 1978, 206-207.

28 Margit, "Dagens frieri", DN 14 January 1936, 8.

29 Alm 2002.

30 Lehtonen 1922, 74-75.

31 Most of the myths about the pygmies did not feature the "isle of bliss" topos. Lahtinen $2017,80$.

32 On the influence of literary Orientalism in Atterbom, see Santesson 1924.

33 Lehtonen 1922, 74-75.

34 Ibid., 99.

35 Lehtonen 1928, 78.

36 "Tapaturmien vuosittaiset vahingot maassamme", HS 15 January 1942, 7, 10.

37 Pekka Tarkka, "Kukkelman - rujo Simson", HS 23 July 1961, 10, Pekka Piirto, "Kiinalaiset ymmärsivät”. HS 15 September 1962, 16.

38 HS 23 February 1950, HS 22 June 1954, HS 1 February 1981.

39 Elmgren 2016, 328.

40 Niemi 2017, 102-103.

41 Ibid., 105.

42 Ibid., 109.

43 On the reception, use, and evolution of the concept neue Sachlichkeit in the Nordic countries, see Hjartarson 2019, 31-40.

44 Essén 1941, 9-30.

45 Ibid., 14.

46 I. H., "Den svenska idyllen", DN 5 February 1942, 4.

47 Tidigs 2009, 370.

48 Zimmer 2008, 183.

49 "Färgrik engelsk beskrivning över lyckolandet Sverige", DN 21 April 1946, 7.

50 "Pressgrannar", DN 23 December 1975, 2.

51 Zimmer 2008, 183, Agrell 1993, 141.

52 "Pressgrannar", DN 3 May 1952, 2.

53 Olof Lagercrantz, "Framtiden som mardröm”, DN 5 January 1960, 4.

54 Nilsson Hammar 2012, 229-230.

55 Karl Erik Lagerlöf, "Happy Marmelade eller rapport från Löfteslandet”, DN 26 March 1976, 4.

56 Wiklund 2006, 334-348.

57 Virtanen 2002, 291-292.

58 Eskola 1968, 122.

59 Ibid., 122.

60 Lahtinen 2017, 80.

61 Eskola 1968, 122-123.

62 Ibid., 128. 
63 Teuvo Mällinen, “Anti Eskola”, HS 18 December 1968, 19.

64 Vesa-Matti Lahti, "Partaradikaalin pitkät jäähyväiset”, HS 6 July 1997, 49.

65 "Kerran kuulut niihin, jotka elivät kauan sitten”, HS 26 March 1969, 13.

66 Sole Uexküll, "Hiukset huiskuvat Hämeessä”, HS 17 August 1969, 16, Pekka Tarkka, "Kansalliskirjallisuuden viikolla", HS 22 February 1970, 24.

67 Matti Klinge, "Kalevalan kansaa etsimässä”, HS 9 December 1969, 19.

68 For a discussion of the book, see Wiklund 2006, 334-337.

69 Wiklund 2006, 335.

70 Kurunmäki 2010, 77.

71 Sjöshult 2011.

72 Eero Silvasti, "Me kuluttajat", HS 22 September 1982, 20.

73 For a discussion of the book, see Marklund 2009, 83-101.

74 Zimmer 2008, 184-185.

75 Lars Anell, "Sverige - ett av världens friaste länder”, DN 5 October 1982.

76 Cronqvist, Kärrholm \& Sturfelt 2008, 37-52.

77 Ibid., 41.

78 Stougaard-Nielsen 2017, chapter 2.

79 Cronqvist, Kärrholm \& Sturfelt 2008, 48.

80 Markku Valkonen, "Kansankoti reistaa mutta minkä tähden”, HS 25 February 1973, 30.

81 Pekka Tarkka, "Taskukirjoista apua valikoimien aukkoihin”, HS 15 September 1974, 28.

82 Lahtinen 2013.

83 Eero Silvasti, "Myrskyn enne?” HS 19 July 1981, 11.

84 Heikki Hellman, "Suomi on kulttuurin lintukoto", HS 4 January 1986, 3, 21.

85 Olli Kivinen, "Kansankoti sekaisin”, HS 19 September 1982, 32.

86 Olli Kangas, "Kansankoti vailla ruotsintautia", HS 29 March 1985, 27.

87 “Den svenska idyllen försvann”, DN 1 March 1987, 5.

88 Olli Kivinen, "Muinaisperinteet ohjaavat tiedotusta", HS 11 May 1986, 40.

89 Olli Kivinen, "Saako luonnon puolesta tappaa?” HS 8 November 1987, 24.

90 Sakari Määttänen, "Lintukodon julkisuus", HS 24 June 1988, 11.

91 Jorma Rotko, "Saarelaisen jäähyväiset”, HS 28 July 1988, 15.

92 Mats Nörklit, "Misstänkt", DN 24 May 1989, 24.

93 Martti Heikkinen, “Nuoret viskoivat tomaateilla ..., HS 18 November 1987, 13.

94 “Siisti ja fiksu, mutta ...", HS 30 December 1987, 11.

95 Osmo Jussila, "Puritaani Jumalan kaupungista", HS 4 June 1988, 14.

96 Anna Paljakka, "Yhdysvaltain maksukorttien markkinat ...", HS 19 July 1988, 18.

97 Kirsikka Moring, "Lintukodossa kaikki hyvin”, HS 17 October 1987, 31.

98 Kirsikka Moring, "Kun teatterin vahakabinetissa palaa", HS 3 September 1988, 33.

99 Unto Hämäläinen, "Tuomiojan haavekuvat ja Kairamon realismi”, HS 28 January 1989, 21.

100 Matti Kinnunen, "Mietosuomalaista itsetutkiskelua", HS 22 February 1990, 21.

101 Jouko Jokinen, "Metsäteollisuus osaa kilpailun rajoittamisen", HS 6 March 1990, 43.

102 Ari Hakahuhta, "Ydinvoimaloiden purkamisesta . . .", HS 7 August 1990, 47.

103 Juhani Aromäki, “Aki Kaurismäen yksinäinen maraton”, HS 23 September 1990, 70.

104 Eero Ojanen, "Lintukotoon Brysseliin”, HS 26 November 1991, B 5.

105 Lahtinen 2017, 83.

106 Ibid., 94.

107 Knuuttila 2008, 12-21.

108 Irmeli Niemi, "Paikalliskulttuurille väylät Eurooppaan ja maailmaan", HS 13 September 1992, 2.

109 Virpi Suutari, "Kaiken varalta”, HS 5 November 1994, 67.

110 Jarkko Sipilä, "Rikollisuus väkivaltaisempaa ja ammattimaisempaa”, HS 14 April 1996, 11.

111 "Pelle Molin och 'Grå jägarn' . .., DN 22 July 1949, 7; "Radio”, DN 25 October 1957, 19, Ingrid Arvidsson, "Vulkaner i medelåldern”, DN 17 January 1966, 4; "Amerikadrömmar på Gubbhyllan”, DN 23 July 1966, 6. 
112 “Svensk hjälp räddar liv . ..", DN 21 October 1964, 21; "De sålde allt de ägde”, DN 23 January 1966, 31; Birgitta Edlund, "Svensk idyll bräcklig fristad för albaner", DN 3 February 1990, A 6.

113 Hannu Marttila, “Ali-ihmisen via dolorosa”, HS 13 April 1986, 20.

114 Nilsson Hammar 2012, 167.

115 Ibid., 50.

116 Reijo Härkönen, "Vieras torjutaan tehokkaasti”, HS 20 August 1988, 26.

117 “Asuntopolitiikka Uudellamaalla”, HS 8 April 1991, 2.

118 Leif Dahlin, "Människosmugglare mutade tull . ..", DN 9 October 1981, 5; Christian Palme, "Väntan på asyl bakom murar . ..", DN 13 December 1984, 18; Christian Palme, "Ny flyktingvåg till Danmark", DN 13 August 1986.

119 Anders Mellbourn, "Valet en stor upplevelse . ..", DN 20 September 1982, 12.

120 Anders Mellbourn, "Iran bannlyser kemiska vapen”, DN 7 July 1984, 10; Anders Mellbourn, "Redo fara till kriget", DN 8/7/1984, 8; Pierre Schori, "Veckan då . ..", DN 29 March 1987, 40.

121 Kerstin Fried, "Ivrig väntan på Katarina”, DN 29 February 1992, 88.

122 Christian Palme, "Styrman på ny seglats", DN 30 December 1990, B 6.

123 "Paradis", DN 1 February 1980, 7.

124 DN 31 May 1984, 54; 17 September 1984, 46; 9 March 1989, 30; 6 July 1990, 37; Jan Källman, "Svensk idyll för européer", 21 May 1990, 5.

125 Mats Holmberg, "Sverige är ett drömland", DN 16 November 1984, 12.

126 Ann Helena Rudberg", Rysarserie i svensk idyll”, DN 21 February 1982, 55.

127 “Titta om du vågar”, DN 25 May 1988, 68.

128 Peder Alton, "Brutala bilder från Paris", DN 5 May 1983, 4; Anders Öhman, "Försvaret är inte så effektivt", DN 31 January 1988, 7; Sören Löfvenhaft, "Inte bara Sörgården”, DN 14 May 1989, 37.

129 Bäckman, “Afrikas blå lilja”, DN 14 July 1990, 11.

130 Britt-Marie Svedberg, “'Här är ditt liv' . ..”, DN 29 March 1982, 57; Jackie Jakubowski, "Dokument om förtvivlans ansikte", DN 4 February 1988, 4.

131 Mårten Blomkvist, " “Leif’ är inte som andra”, DN 26 June 1987, 18.

132 Johannes Åman, “Upptäckten av framtiden . ..”, DN 22 September 1990, 2.

133 Buck-Morss 2000, 68.

134 Betz 1993, Poutvaara \& Steinhardt 2018.

135 Norstedt \& Söner 1933, 402.

136 Jac, “Den svenska idyllen”, DN 31 December 1935, 10.

\section{References}

\section{Newspapers}

Accessed through the digital archives of Helsingin Sanomat (HS) and Dagens Nyheter (DN). For Helsingin Sanomat, the digital archives of the Finnish National Library were also utilized.

\section{Literature}

Agrell, Beata, 1993: Romanen som forskningsresa, forskningsresan som roman. Daidalos: Göteborg. Alm, Martin, 2002: Americanitis: Amerika som sjukdom eller läkemedel. Lund: Nordic Academic Press.

Atterbom, Per Daniel Amadeus, 1827: Lycksalighetens ö. Sagospel i fem äfventyr. Sednare afdelningen. Uppsala: Palmblad \& Co.

Betz, Hans-George, 1993: “The New Politics of Resentment: Radical Right-Wing Populist Parties in Western Europe" in Comparative Politics, 7:1, 413-427. 
Buck-Morss, Susan, 2000: Dreamworld and Catastrophe: The Passing of Mass Utopia in East and West. Cambridge, MA: MIT Press.

Cronqvist, Marie, Kärrholm, Sara \& Sturfelt, Lina, 2008: "Oro i lyckolandet - Mellan Sofiero och Norrmalmstorg" in Marie Cronqvist, Lina Sturfelt \& Martin Wiklund (eds.) 1973: En träff med tidsandan. Lund: Nordic Academic Press, 37-55.

Elmgren, Ainur, 2016: "Förfinskandet av Finland: Självexotism i den finländska kulturdebatten under första hälften av 1900-talet" in Mats Wickström \& Charlotta Wolff (eds.) Mångkulturalitet, nation och minoriteter $i$ Finland under tre sekel. Helsingfors: SLS, 319-354.

Eriksson, Gunnar, 2002: Rudbeck 1630-1702: Liv, lärdom, dröm i barockens Sverige. Stockholm: Atlantis.

Eskola, Antti, 1968: Suomi sulo Pohjola. Helsinki: Kirjayhtymä.

Essén, Rütger, 1941: Den svenska idyllen: nio dialoger. Helsingfors: Söderströms.

Harva, Uno, 1948: Suomalaisten muinaisusko. Porvoo: WSOY.

Hjartarson, Benedikt, 2019: "Cosiness and Subversion: From Post-Cubism to Functionalism and 'Scandinavian Surrealism'" in Benedikt Hjartarson et al. (eds.) A Cultural History of the Avant-Garde in the Nordic Countries 1925-1950. Leiden: Brill, 1-79.

Karvinen, Matti, 2015: Lintukodosta Pohjolan onnelaksi: Suomen mahdollisuudet ja tulevaisuus vuonna 2040. Helsinki: Suomalaiset Oikeusjulkaisut SOJ.

Knuuttila, Seppo, 2008: "Impivaara suomalaisten symbolina" in Seppo Knuuttila et al. (eds.) Entinen aika, nykyinen mieli. Suomalaisen Kirjallisuuden Seuran toimituksia 1185. Helsinki: SKS, 12-21.

Koselleck, Reinhart, 2006: "Fortschritt und Niedergang: Nachtrag zur Geschichte zweier Begriffe" in Reinhart Koselleck (ed.) Begriffsgeschichten: Studien zur Semantik und Pragmatik der politischen und sozialen Sprachen. Frankfurt a. M.: Suhrkamp, 159-181.

Kurunmäki, Jussi, 2010: “ "Nordic Democracy' in 1935: On the Finnish and Swedish Rhetoric of Democracy" in Jussi Kurunmäki \& Johan Strang (eds.) Rhetorics of Nordic Democracy. Helsinki: Finnish Literature Society, 37-82.

Lagerroth, Ulla-Britta, 1978: Regi i möte med drama och samhälle: Per Lindberg tolkar Pär Lagerkvist. Stockholm: Rabén \& Sjögren.

Lahtinen, Jussi, 2013: Duunarin tarinoita murroksen yhteiskunnasta: Romaanihahmojen arkisia käsityksiä ja kokemuksia suomalaisesta palkkatyöyhteiskunnasta 1960-1970-lukujen työläiskirjallisuudessa. Master's thesis. Tampere: Tampereen yliopisto.

Lahtinen, Toni, 2017: "Keskellä iäisyyden myrskyjä: Onnen ja nälän saaret Aleksis Kiven tuotannossa" in Maria Laakso et al. (eds.) Lintukodon rannoilta: Saarikertomukset suomalaisessa kirjallisuudessa. Helsinki: Suomalaisen Kirjallisuuden Seura, 70-97.

Lahtinen, Toni, Laakso, Maria \& Sagulin, Merja, 2017: “Johdatus suomalaisen kirjallisuuden saarille" in Maria Laakso et al. (eds.) Lintukodon rannoilta: Saarikertomukset suomalaisessa kirjallisuudessa. Helsinki: Suomalaisen Kirjallisuuden Seura, 9-43.

Lehtonen, J. V., 1922: Aleksis Kivi taiteilijana: eräitä piirteitä. Porvoo: WSOY.

Lehtonen, J. V., 1928: Runon kartanossa: johdatusta Aleksis Kiven runouteen. Helsinki: Otava.

Marklund, Carl, 2009: "Hot Love and Cold People: Sexual Liberalism as Political Escapism in Radical Sweden" in NORDEUROPAforum, 19:1, 83-101.

Niemi, Juhani, 2017: "Lintukodosta Letheen: Onnellisten saaren muunnelmia Joel Lehtosen myöhäistuotannossa" in Maria Laakso et al. (eds.) Lintukodon rannoilta: Saarikertomukset suomalaisessa kirjallisuudessa. Helsinki: Suomalaisen Kirjallisuuden Seura, 98-111.

Nilsson Hammar, Anna, 2012: Lyckans betydelse: sekularisering, sensibilisering och individualisering i svenska skillingtryck 1750-1850. Lund: Agerings bokförlag.

Norstedt, P. A. \& Söner (eds.), 1933: Vem är det: Svensk biografisk handbok. Stockholm: P. A. Norstedt \& Söner. 
Östlund, Joachim, 2007: Lyckolandet: maktens legitimering $i$ officiell retorik från stormaktistid till demokratins genombrott. Lund: Sekel.

Poutvaara, Panu \& Steinhardt, Max Friedrich, 2018: "Bitterness in Life and Attitudes Towards Immigration" in European Journal of Political Economy, 55, 471-490.

Riikonen, H. K., 2017: "Ylitse meren yhdeksän: Saaria Elias Lönnrotin Kalevalassa" in Maria Laakso et al. (eds.) Lintukodon rannoilta: Saarikertomukset suomalaisessa kirjallisuudessa. Helsinki: Suomalaisen Kirjallisuuden Seura, 47-69.

Santesson, Carl, 1924: "Exotism och orient i 'Lycksalighetens ö"” in Samlaren: Tidskrift för svensk litteraturhistorisk forskning. Ny följd. Årgång 4, 1923. Skrifter utgivna av Svenska Litteratursällskapet 1. Uppsala: Almqvist \& Wiksells Boktryckeri AB, 98-171.

Sjöshult, Fredrik, 2011: "Reinfeldt: Palme radikaliserade S” in Expressen, 25 February 2011. www.expressen.se/nyheter/reinfeldt-palme-radikaliserade-s/ [Accessed 29 May 2018].

Stagnelius, Erik Johan, 1833: J. Stagnelii samlade skrifter, utgifne af L. Hammarsköld. Tredje delen. Stockholm: A. Wiborgs Förlag.

Stougaard-Nielsen, Jakob, 2017: Scandinavian Crime Fiction. London: Bloomsbury.

Stråth, Bo, 1998: Mellan två fonder: LO och den svenska modellen. Uddevalla: Atlas.

Tanner, Kerttu, 1954: Myttilliset tarinat suomalaisessa taidelyriikassa. Turku: Turun yliopisto.

Tidigs, Julia, 2009: "Multilingualism, Modernism and (De)Territorialization in Elmer Diktonius" in Sascha Bru et al. (eds.) Europa! Europa? The Avant-Garde of Modernism and the Fate of a Continent. Berlin: Walter de Gruyter, 359-372.

Toggweiler, Michael, 2017: Die Odyssee der Pygmäen. Eine andere Geschichte der neuzeitlichen Anthropologie. Bern: Philosophisch-historische Fakultät, Universität Bern.

Topelius, Zacharias, 1891: Läsning för barn. Sjunde boken. Visor, sagor och lekar. Helsingfors: G. W. Edlund.

Vetterlund, Fredrik, 1920: "Per Daniel Amadeus Atterbom," in Svenskt Biografiskt Lexikon. urn:sbl:18908. https://sok.riksarkivet.se/sbl/artikel/18908 [Accessed 12 February 2021].

Virtanen, Matti, 2002: Fennomanian perilliset: Poliittiset traditiot ja sukupolvien dynamiikka. Hämeenlinna: SKS.

Wiklund, Martin, 2006: I det modernas landskap: Historisk orientering och kritiska berättelser om det moderna Sverige mellan 1960 och 1990. Stockholm: Symposion.

Zimmer, Frank, 2008: Engagierte Geschichte/n: dokumentarisches Erzählen im schwedischen und norwegischen Roman 1965-2000. Frankfurt am Main: Peter Lang. 